\title{
Effect of deformation depth on plantar soft tissue behavior
}

\author{
Jee Chin Teoh, Bena Lim, Taeyong Lee \\ From 4th Congress of the International Foot and Ankle Biomechanics (i-FAB) Community \\ Busan, Korea. 8-11 April 2014
}

\section{Introduction}

Most in vivo indentation techniques are limited by the lack of adequate indentation on the plantar tissue. Without sufficient indentation into the soft tissue, only very little and less representative information can be obtained. The purpose of this study is hence to assess the effect of deformation depth on plantar tissue behavior and to establish a set rule of optimum indentation depth that is sufficient to quantify the critical plantar soft tissue behavior.

\section{Methods}

20 young subjects (20-25 years) participated. During the testing, the indenter [1] probed the second metatarsal head (MTH 2) and heel pad tissue with constant rate of
$12 \mathrm{~mm} / \mathrm{s}$. Experiment was done under load bearing (50\% $\mathrm{BW}$ on foot tested) condition. Maximum tissue deformation induced was varied from $1.2 \mathrm{~mm}$ to $6.0 \mathrm{~mm}$ in steps of $1.2 \mathrm{~mm}$. Tissue stiffness obtained from tissue response curve was compared.

\section{Results}

All 20 subjects showed similar force response as demonstrated in Fig. 1, at both sites. The soft tissue response was fitted to the viscoelastic model proposed [2], represented by Equation (1).

$$
F=\left\{\begin{array}{lr}
K_{1} X & 0 \leq X \leq X_{s} \\
K_{1} X+K_{2}\left(X-X_{s}\right)+C X, & X_{s} \leq X \leq X_{\max }
\end{array}\right.
$$

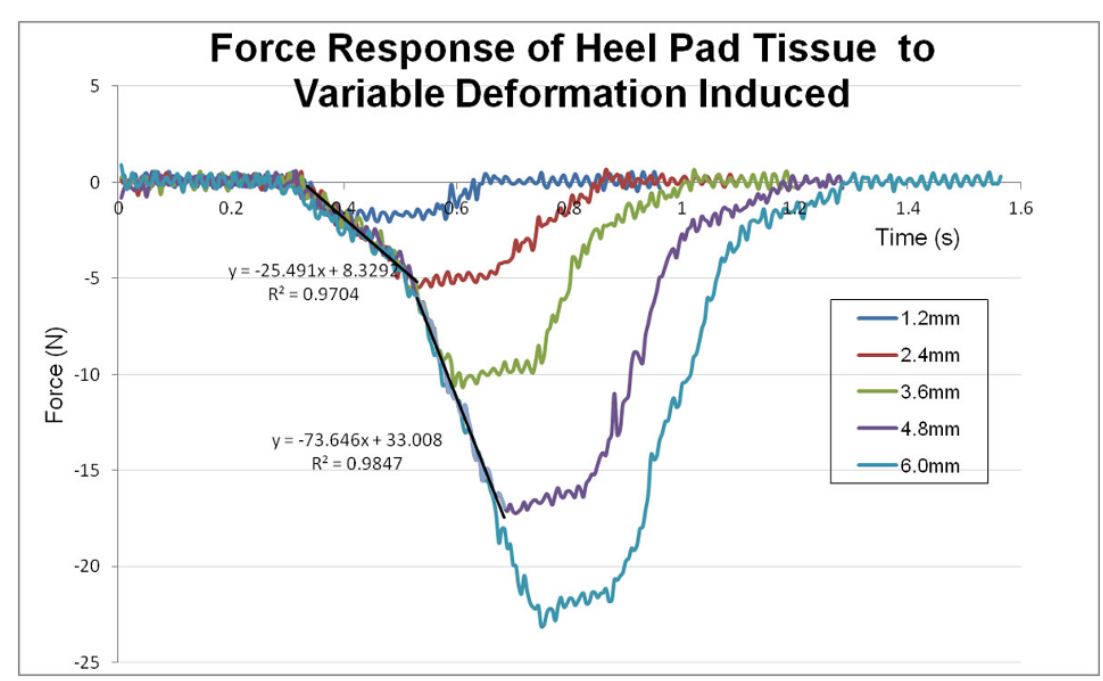

Figure 1 Typical force response of plantar soft tissue to the variable indentation depth.

* Correspondence: bielt@nus.edu.sg

Department of Biomedical Engineering, National University of Singapore, Singapore 
Table 1 Tissue properties of $2^{\text {nd }}$ MTH and heel

\begin{tabular}{llll}
\hline & $\mathbf{2}^{\text {nd }} \mathbf{M T H}$ & Heel & p-value \\
\hline Average Tissue Thickness $(\mathbf{m m})$ & $13.80 \pm 1.76$ & $18.04 \pm 2.42$ & $<0.01^{*}$ \\
\hline $\mathbf{K}_{\mathbf{1}}$ (\% tissue thickness $\left./ \mathbf{m m}\right)$ & $-0.230 \pm 0.122$ & $-0.492 \pm 0.151$ & $<0.01^{*}$ \\
\hline $\mathbf{K}_{\mathbf{2}}(\%$ tissue thickness $/ \mathbf{m m})$ & $-0.477 \pm 0.168$ & $-1.015 \pm 0.406$ & $<0.01^{*}$ \\
\hline $\mathbf{X}_{\mathbf{s}}$ (\% tissue thickness) & $16.177 \pm 1.909$ & $11.845 \pm 1.284$ & $<0.01^{*}$ \\
\hline $\mathbf{C}$ & $0.767 \pm 0.667$ & $1.803 \pm 0.651$ & $0.03^{*}$ \\
\hline
\end{tabular}

*significant at $95 \%$ confidence level

As the indenter tip goes deeper into the soft tissue beyond a threshold depth, the force gradient will increase notably. $K_{1}$ and $K_{2}$ depict the elastic components of soft tissue at the initial and subsequent phases of indentation. $\mathrm{C}$ characterizes the viscous behavior of tissue which is only prominent at the latter stage of indentation. $\mathrm{X}_{\mathrm{s}}$ is the minimum indentation depth required for the tissue to exhibit nonlinear viscoelastic behavior. The parameters are listed in Table 1.

\section{Discussion}

As the indentation gets deeper, the stiffer the soft tissue becomes. We found that indentation depth which is less than the threshold depth might not be representative of the nature of plantar soft tissue. This small tissue deformation does not reflect the critical condition of soft tissue during physical activities that will expose the tissue to risk of ulceration. The threshold depth is subject dependent and is very likely to be caused by the difference in tissue composition. The next key step is to further investigate how the tissue composition will affect the threshold thickness in each subject.

The study successfully indicated the necessity to induce sufficient indentation to the soft tissue tested, in order to describe its true nature. This will eventually provide a more useful stiffness values in identification of potentially abnormal soft tissue.

Published: 8 April 2014

\section{References}

1. Chen W, et al: An instrumented tissue tester for measuring soft tissue property under the metatarsal heads in relation to metatarsophalangeal joint angle. Journal of Biomechanics 2011, 44:1804-1804.

2. Klaesner JW, et al: Accuracy and reliability testing of a portable soft tissue indentor. Neural Systems and Rehabilitation Engineering 2001, 9(2):232-240, IEEE Transactions on.

doi:10.1186/1757-1146-7-S1-A84

Cite this article as: Teoh et al:: Effect of deformation depth on plantar soft tissue behavior. Journal of Foot and Ankle Research 2014 7(Suppl 1): A84.
Submit your next manuscript to BioMed Central and take full advantage of:

- Convenient online submission

- Thorough peer review

- No space constraints or color figure charges

- Immediate publication on acceptance

- Inclusion in PubMed, CAS, Scopus and Google Scholar

- Research which is freely available for redistribution

Submit your manuscript at www.biomedcentral.com/submit 